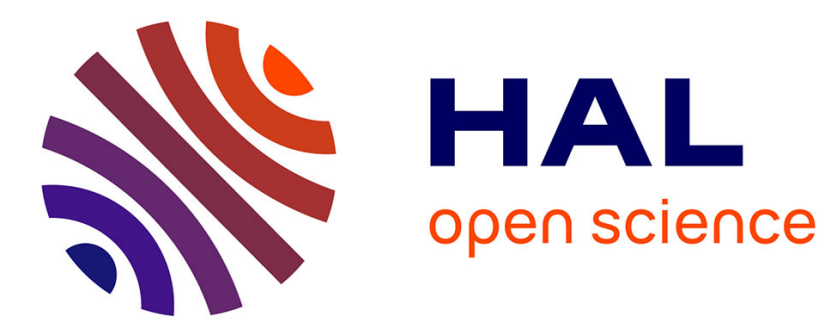

\title{
Land grabbing, legal contention and institutional change in Colombia
}

Jacobo Grajales

\section{To cite this version:}

Jacobo Grajales. Land grabbing, legal contention and institutional change in Colombia. Journal of Peasant Studies, 2015, Journal of Peasant Studies, 42 (3-4), pp.541-560. 10.1080/03066150.2014.992883 . hal-01316040

\section{HAL Id: hal-01316040 \\ https://hal.science/hal-01316040}

Submitted on 10 Jun 2021

HAL is a multi-disciplinary open access archive for the deposit and dissemination of scientific research documents, whether they are published or not. The documents may come from teaching and research institutions in France or abroad, or from public or private research centers.
L'archive ouverte pluridisciplinaire HAL, est destinée au dépôt et à la diffusion de documents scientifiques de niveau recherche, publiés ou non, émanant des établissements d'enseignement et de recherche français ou étrangers, des laboratoires publics ou privés. 
Published as: Jacobo Grajales, J. 2015. Land Grabbing, Legal Contention and Institutional Change in Colombia. The Journal of Peasant Studies, 42(3-4), 541-60.

\title{
Land grabbing, legal contention and institutional change in Colombia
}

\author{
Jacobo Grajales
}

\begin{abstract}
The entanglement of violence and legal institutions in Colombia has led some scholars to argue that this country is characterized by a 'law without state', or that the law has a mere 'symbolic function'. This would explain an apparent paradox: high intensity violence has been accompanied by the preservation of legal institutions and a common belief in their social importance. Yet the mobilization of the legal repertoire against violent land grabbing by peasant movements shows their belief in the legitimacy of legal institutions. Instead of measuring the efficiency of these actions, this paper will analyse the interaction between local orders and national legal institutions. This study argues that legal arenas have served to address land conflict, in a context of egregious violence. With their own dynamics and rules, they have not completely disrupted the logics of violent dispossession, yet they have defined land not only as an object of business transactions but also as an issue of human rights and collective identities.
\end{abstract}

\section{Introduction}

Colombia is a particularly interesting case for land grabbing analysts, as it combines political and economic incentives to develop agribusiness with a development discourse centred on global markets, while involving criminal actors who are able to use physical violence and bureaucratic connections in order to seize and accumulate land. 
Yet, Colombia is also a highly judicialized polity, with a strong tradition of legal contention and cause lawyering. Moreover, a certain number of formal rights run in favour of the dispossessed peasant population; there is a relatively strong recognition of land rights, which has been reinforced by the recently enacted 'Land and Victims Law'. Yet, these formal rights suffer from prosaic, underground and violent forms of reaction on the part of the new land owners, often linked to paramilitary militias.

In Colombia, land grabbing has been seized as an opportunity for large investors and armed actors to launder illegal assets and to transform the power of violence into a legitimate capital. The complexity of the legal field has been both an opportunity for land grabbers, and a potential vector of resistance for local communities. The international visibility of the Colombian conflict, and the commitment of international human rights organizations have given extra resources to domestic actors, and have transformed land grabbing into a public problem in Colombia. Yet, in the lack of a real peace building process and an effective enforcement of the rule of law, land ownership might remain an issue of violent contention for years to come.

The assessment of the linkages between political contention and the legal arena in Colombia will show the potentialities and obstacles for the use of this strategy in land grabbing issues. Contrary to Blanquer (2002), who considers that in Colombia there is 'law without state', I will argue that this country's situation is characterized by a combination of legal and illegal strategies presiding at the distribution of power and resources. Despite the magnitude of violence, legal institutions are not a mere 'veil', which hides the cruelty of dispossession and repression. Neither are they intrinsically progressive arenas, essentially opposed to the ruling of violence. Judicial institutions are a central locus of political conflict, governed by specific rules, but as dependent on the global distribution of power as the rest of society.

The next section of the paper will present the theoretical framework and the empirical case that will allow us to deal with the apparent paradox underlying this story: high intensity violence has been accompanied by the preservation of legal institutions and the common belief in their social importance. The subsequent section of the paper will examine the specific case of judicialization of land grabbing. We will show that, despite the egregious violence that has affected the country for decades, legal institutions have not only been kept alive but also strengthened. Colombian judges specifically the Constitutional Court - have recognized the rights of forcibly displaced communities to recover grabbed land. More broadly, the judicialization of these issues has been accompanied by 
its internationalization, with the intervention of the Interamerican Human Rights Court on behalf of the communities.

\section{Land grabbing and judicialization of politics}

\section{Colombia: the paradox of law and order}

The concept of 'judicialization of politics' points at a historical process where courts and judges have gained influence in political processes and where widespread popular demand is addressed to these actors in a great variety of topics (Sieder, Schjolden, Angell 2005). Cepeda (2005) points at a Colombian paradox, with a strong tradition of judicial review coexisting with high levels of violence and human rights violation. Judicialization of politics is defined, in the Colombian situation, as a 'twofold process by which, first, legal arguments are raised in the course of the political process, as a consequence of relevant judicial decisions [...] second, constitutional judges end up substantially contributing to the orientation of the public policy' (Cepeda 2005, 68)

Yet, Colombia also presents a fragmented political order, with a high degree of autonomy for local powers, and an entanglement of legal political actors and criminal networks in the periphery (Ballvé 2013, Duncan 2005, Romero 2007, Romero 2011, Grajales 2013). Historically, the Colombian state has been characterized by the weight of peripheral elites in the formation and maintenance of local orders (Bushnell 1993). The authority of the centre has not been built over the direct control of local institutions, but on a strategy of discharge, leaving the responsibility of peripheral control including on security issues - with local elites associated to the state. The weakness of the centre has been partially compensated by the distribution of resources through the national parties, tying the destiny of local leaders to their alliances with the central partisan elites ${ }^{1}$; these local orders are not entirely based on violence, but also on the distribution of resources and services; such domination dynamics have been described by Fox (1994), in the Mexican context as 'authoritarian clientelism'. ${ }^{2}$ This system was disturbed by the rise of a new group of professional politicians linked to drug smugglers and paramilitary militias. Thanks to their shadowy allies, these 'nouveaux riches' were less dependent on national leaders (Leal Buitrago, Davila 1990; Gutierrez 2007). In consequence, they intended - and sometimes managed - to create peripheral orders relatively autonomous from the centre. This process can be described as an instance 'subnational authoritarianism', defined by Gibson as

This process of discharge is remarkably well described by Lopez-Alves (2003) and Roldan (2002)

See also Cornelius et al. (1999) and Gibson (2005) for a critical assessment of democratization in fragmented societies. 
The existence of a democratic national government alongside a provincial authoritarian government within the nation-state (...). Two levels of government with jurisdiction over the same territory operate under different regimes, understood as the set of norms, rules, and practices that govern the selection and behavior of state leaders (Gibson 2005, 103)

The establishment of these authoritarian enclaves transcends the private/public division; it is not only a matter of official institutions and formal legal mechanisms, but more broadly it engages a formal and informal 'bundle of powers' (Peluso and Lund 2011; Lund 2011) exercised by different actors gathered by common economic interests. The establishment of these enclaves does not lead to the isolation of local power arenas. On the contrary, they are characterized by the overlapping of legal and informal orders (Gibson 2005; Franco 2008)

How can we interpret this coexistence of judicial institutionalization and violent fragmentation of the polity? Through a study of strategies of land grabbing, as well as resistance to land grabbing, this contribution argues that law and violence are not antithetical elements, but participate in diverse ways to the historical process of State formation (Briquet and Favarel-Garrigues 2010). This analysis is comparable to Gayer's approach to the city of Karachi in terms of 'ordered disorder' as a situation where 'endemic forms of collective [...] violence' do not lead to a situation of Hobbesian chaos and 'do not preclude the existence of a democratic order and a thriving economy' (Gayer 2014, 12). According to Gayer, social order does not necessarily equate with the control and monopolization of violence, but can be defined as the existence of

underlying principles (the rules of the game) of a historical figuration, in Elias' sense of a 'game structure' organised around interdependent actors and reproducing itself through a 'fluctuating, tensile equilibrium' (Elias), which may accommodate a significant level of competition over the means of coercion' (Gayer 2014, 13).

The judicialization of politics, and more broadly social conflict, can be analysed as a situation of 'ordered disorder'. This is convergent with Comaroff and Comaroff's arguments, that, following Derrida and Agamben, point out empiric situations where the 'violence and the law, the legal and the lethal are constitutive of one another' (Comaroff, Comaroff 2008, X). According to these scholars:

Both the anxiety and the fascination point to a very general preoccupation in the postcolonial world with "the law" and the citizen as legal subject, a preoccupation 
growing in counterpoint to, and deeply entailed in, the rise of the felonious state, private indirect government, and endemic cultures of illegality. (Comaroff, Comaroff 2008, 20)

In consequence, contemporary politics in the post-colony are characterized by a displacement of the political into the legal and by the belief that courts and legal provisions offer a 'repertoire of more or less standardized terms and practices that permit the negotiation of values, beliefs, ideals and interests across otherwise-impermeable lines of cleavage' (Comaroff, Comarof 2008, 32) .

Land grabbing cases are relevant points of observation for the study of problems of law, order and violence. As stressed by Lucia Goldfarb (2012) in the case of Argentina, the judicialization of conflicts for land control and property engage both the companies seeking to secure their investments and social movements opposed to the commoditization of land and the expansion of certain crops (genetically modified crops for instance). In the Colombian case, violent land grabbing needs to be legalized in order to integrate the land into the agribusiness market; legalization is possible thanks to the association of local politicians, business actors and paramilitary groups (Ballvé 2013, Goebertus 2008, Grajales 2011, Grajales 2013). This recognition is particularly relevant for criminal actors, as the sustainability of their operations depends on their capacity to convert criminal profits into legal capital, to 'launder' those assets, i.e. to integrate them into the legal market. Therefore, it does not suffice to occupy a plot; the profitability of land grabbing requires the institutional recognition of property rights over those spurious holdings.

Furthermore, I will also argue that an approach that embraces law and violence, the legal and the lethal, is rich for the study of land grabbing. Such a large conception of the legal field encompasses strategies of resistance, denunciation and protection, but also land accumulation and violent dispossession. Consequently, following Borras and Franco (2013), this paper aims to problematize the reaction to land grabbing; these two authors show how the impact of land deals, state-sponsored land grabbing and/or violent dispossession is not uniform. In consequence, political actors' reactions must be addressed with a sociological lens, in order to show which are the institutional, historical and sociological conditions that determine reaction to land grabbing. In this contribution, the role of the State will be characterized as ambiguous and diverse, as it facilitates land grabbing but it also shapes the structure of political opportunities that determines collective action and repertoires. Such an ambiguity can only be addressed through the idea that state formation is inseparable from processes of territorialization, integration to the market and resource commoditization. 


\section{Paramilitary violence and land grabbing}

According to a study of the Magdalena University, two thirds of internally displaced persons (IDPs) in the Colombian Caribbean lowlands were peasants (Barbosa et al. 2007). Whether they had an individual legal title deed over their land or any other form of right (collective titles, right of occupancy...), their forced migration addressed the question of land ownership and land grabbing. The minority of those who tried to return to the countryside, challenging the lethal threat represented by armed groups (guerrilla and paramilitaries), found that forced displacement had given way to land grabbing. In some cases, paramilitary militias had repopulated the vacated zones with loyal individuals - friends or family members of their rank-and-file. But in most cases, grabbed land had been integrated into existing farms; frequently contributing to the expansion of the country's flourishing agribusiness. High value crops - oil palm in the first place - started to be produced in those plots forcibly abandoned by small peasants. The perpetrators of this massive land grab were corporations linked to the paramilitary commanders, directed by their families or frontmen. Other companies and businessmen, attracted by agribusiness, were willing to pay an informal tax to these paramilitary entrepreneurs, and profit from this new 'agrarian frontier'.

This section will analyse a specific case of land grabbing and further legal mobilization. Between 1996 and 1998, 17,000 people were forced to leave the region of the Lower Atrato valley, in the Chocó province (North-west); they were fleeing from the violence of a massive counter-insurgent campaign deployed by the military and paramilitary militias. According to the Colombian Institute for Rural Development (Incoder), in 2005 twelve firms occupied more than 26,000 ha, and had planted more than 5,000 ha of oil palm.

In 2005, after the communities' long-standing mobilization, supported by national nongovernmental organizations (NGOs), the case was taken to the Inter-American Human Rights Commission, and a series of official inquiries confirmed the link between forced displacement and land grabbing. While the Lower Atrato people enjoyed specific rights as 'Afro-Colombians', the force of weapons was, at least initially, stronger than the force of law. Such a conclusion is consistent with Li's findings (2011); this author considers that the existence of formal rights is dependent on the structure of the society and the unequal distribution of power. Indeed, it is generally recognized that land rights recognition is not a sufficient asset for communities to protect their access to land (Vermeulen, Cotula 2010). The Lower Atrato case exemplifies the fact that, while 'legal empowerment' has a positive effect on these communities, bargaining capacity is mostly determined by the economic order and its underlying power relations (Cousins 2009). 
This case is one of the best-documented instances of violent land grabbing and has been abundantly studied (Ballvé 2013, Grajales 2013, Restrepo, Franco 2011, Rolland 2007). The abundance of information is mainly due to the intervention of the Inter-American Commission for Human Rights and the Colombian Constitutional Court, both of which called for a variety of official surveys on this issue, mainly from institutions such as the General Controller (Contraloria General) or the General Inspector (Procuraduria General). The Lower Atrato case illustrates the link between land grabbing and the fragmentation of the political order, as it remained a paramilitary enclave for almost a decade. Consequently, legal mobilization aimed to nationalize (and internationalize) the conflict, in order to revert the legal and political marginalization of this territory.

The Lower Atrato is an extremely marginal region, populated by the descendants of African slaves and located under the scope of influence of different regional poles. ${ }^{3}$ In the absence of regional elite, the paramilitary control of the region was not, as elsewhere in Colombia, the result of an alliance between powerful local actors. On the contrary, it was a sort of 'armed colonization', where violent white/mestizo entrepreneurs got rid of the local black population, whose land was considered 'vacant' (Oslender 2007). In consequence, the constitution of an authoritarian enclave is not only the result of the local power holders' strategy. It is also - and mostly - the consequence of a situation of geographical, political and ethnic marginality.

The paramilitary advance came from the northern region of Urabá, one of the country's most important agribusiness poles. This armed strategy was crafted as a response to the FARC guerrillas' threat - historically present in the region - as well as the need for vacant land to expand the agribusiness economy of Urabá. Paramilitary harassment was joined and accompanied by official counter-insurgency operations. From early 1997, military forces from the 17th Brigade deployed intense bombing against presumed guerrilla positions. ${ }^{4}$ This bombing was indiscriminate, and forced the population to leave their houses and hide in the jungle. After the bombing the army troops were brought in by helicopters and entered the villages. They gathered the locals and warned them about the obligation to cooperate with them and provide them with information about the guerrillas.

3 The Colombian Pacific Lowlands region has been studied by Escobar (2008); he apprehends the Colombian government policies in this region as determined by both the neoliberal agenda, that led to the development of agribusiness, and the multicultural paradigm that allowed the emergence of black and indigenous social movements.

4 The collaboration between paramilitary groups and the military in the Uraba region was included in a criminal investigation against General Rito Alejo del Rio, convicted in 2012 for the murder of a peasant during these joint operations. The description of the 1996-1997 armed operations are based on the Del Rio trial. 
According to the confessions of the former chief of the $\mathrm{AUC}^{5}$ in the region, Fredy Rendón, 12 of his men participated in these military operations. They had precise knowledge of the region, and acted as 'guides'. In the aftermath of bombings and harassments, more than 4,000 people left the region and sought refuge in neighbouring towns, as well as beyond the Panamanian border.

Shortly after the eviction of the Lower Atrato inhabitants, oil palm crops were planted; they were part and parcel of a violent territorial appropriation project. According to some testimonies, one of the paramilitary leaders' motivations was to colonize this region with demobilized militiamen, while simultaneously making good use of the investment in land for money laundering operations. ${ }^{6}$ One of the key men of this strategy was Vicente Castaño, the AUC's head of finance. His business strategy vision was not opposed to that of state institutions; on the contrary, it was intertwined with official statements on economic development:

We have palm crops in Urabá. I found the businessmen myself to invest in those projects that are durable and productive. The idea is to bring the rich to invest in such projects in different parts of the country. By bringing rich people to these areas, state institutions will come. Unfortunately, the state institutions only come when you are rich. We must bring those rich businessmen all over the country; that is one of our commanders' missions' (Semana, 2005).

The creation of the first Lower Atrato palm firm, Urapalma, by Vicente Castaño, took place in 1999. Urapalma's board of directors was controlled by his friends and relatives (El Espectador 2010). Asoprobeba, another palm firm in the region, was controlled by Sor Teresa Gómez, a Castaño relative and an active member of the AUC. Asoprobeba was supposed to be a non-profit foundation formed by more than 100 peasant families. The beginnings of palm business also attracted entrepreneurs engaged in agribusiness in other zones of the Caribbean lowlands.

Legal strategies played a key role in the process of violent land grabbing. The profitability of the land grab depended on the regularization of title deeds, or at least on the legalization of the commercial exploitation of land. Transfer of property rights was made through clear-cut criminal means - falsifying title deeds, for instance. Such practices implied the collaboration of notaries and

\footnotetext{
5 The United Self-Defence Forces of Colombia (Autodefensas Unidas de Colombia) was a confederation of paramilitary militias, strongly linked to large landowners, narcotraffickers and local politicians. Negotiations held between the government and the AUC representatives between 2003 and 2005 led to the formal demobilization of these groups. Most of its leaders were extradited to the United States for drug traffic charges. An undetermined share of the medium-level commanders and the rank-and-file created new armed groups or joined existent militias linked to drug smuggling.

$6 \quad$ Author interviews, Bogota, January and February 2011.
} 
public officials, and illustrate the entanglement of local institutions and paramilitary groups (Restrepo, Franco 2011). Other methods took advantage of the issue of overlapping title deeds and loose boundaries. For example, a number of plots were purchased from people claiming de facto right of tenure, determined by the mere occupancy of land.

Even more complex strategies were equally used. Some agribusiness companies obtained effective land control without purchasing the plots. Land transfer was operated through usufruct contracts or 'strategic alliances'. Usufruct contracts transfer the effective control over land and land-based profits, and were signed by people who claimed title deeds over land or who enjoyed a representative mandate in the community councils. In most cases, the community councils denied that they had granted this mandate to the contractors; some cases might be simple impersonation, while others could indicate divisions among the community councils.

The creation of the legal framework for 'strategic alliances' was among the first responses of the national government to the issues of land grabbing. It permitted the association of local communities and palm oil firms in order to use former collective territories in agribusiness projects. Strategic alliances were initially presented as a remedy to land grabbing issues, thus making the interests of community councils and those of agribusiness firms compatible. One of the consequences of such alliances was the availability of subsidies reserved for projects launched within strategic alliances, which made them even more attractive to agribusiness companies.

As a consequence of the economic importance of the palm oil market, the Colombian government adopted a program of subsidies for the palm industry during the 2000s. These subsidies were abundantly allocated to the Lower Atrato firms, even after severe criticism had been expressed by the Inter-American Commission and the Ombudsman Bureau (Defensor del Pueblo). Lower Atrato firms received millions in public subsidies for several years. Urapalma, for instance, received substantial credit from Finagro (public fund for agricultural development), for more than 2.5 million dollars. A 2009 Controller Bureau report found that Finagro had approved credit for more than 7.5 million dollars. Urapalma received 89 per cent of all the Rural Credit Incentives distributed in the Lower Atrato. Urapalma even got funds through US Aid; thanks to its participation in a program of illegal crop substitution, the firm received more than 6 million dollars from the American government agency. ${ }^{7}$

The brief account of the Lower Atrato case shows that the convergence of state action and violent land grabbing in Colombia is not the result of a lawless situation (Taussig 2003), but the outcome of

Ballvé (2013), as well as Restrepo and Franco (2011) abundantly explore the issue of the links between criminal and corporate actors. 
the convergence between legal strategies, violent coercion and criminal networks. Unlike the situations of Sierra Leone and Belize described respectively by Reno (2008) and Duffy (2008) private violent accumulation does not engage the whole state apparatus (described as a 'shadow state' by these authors) but is a central element of intra-state conflicts. The contentious dimension purported by these criminal networks constitutes the pivotal condition for resistance and denunciation. The following pages will show that, if legal arenas can be a locus of the legalization of dispossession they also can supply the resources for mobilization. The translation of land grabbing issues into the human rights frame will exemplify this point.

\section{Violence, justice and human rights}

The case of the Lower Atrato, but more broadly the paramilitary problem, could lead us to conclude that Colombia experienced during those years a process of 'partial State failure', ${ }^{8}$ or that politics in that country are characterized by a 'criminalisation of the State', ${ }^{9}$ as seems to believe Avilés (2007) when he argues that the privatization of violence and the implementation of neoliberal reforms are part and parcel of the domination of a globalized technocratic elite.

Yet, the enormous difficulties experienced by the legal system when dealing with political and prosaic violence do not mean that courts and judges have lost their legitimacy to interpret and enforce the law (Uprimny 2007). On the contrary, violence has been accompanied in Colombia by the continuous belief in the social role of the legal system, reaffirmed by common citizens as well as by political actors. For some scholars, like Julieta Lemaitre (2009), the reliance of social movements on the law is not only a matter of strategy and repertoires, but of social representations as well. For Lemaitre, in a context of intense violence, the usage of law by social movements helps to give a meaning to violent experiences and to build collective identities. More specifically, the dominant narrative used by these organisations to describe the Colombian situation is international humanitarian law. According to Winifred Tate (2007), the usage of the category of 'human rights violations' to describe a particular situation comes down to a categorisation of violence and generates specific kinds of social obligations, namely urging the state to protect the population.

The usage of international law as a social narrative has not lead to a marginalisation of national law. On the contrary, domestic jurisdictions have interpreted and integrated the international treaties and jurisprudence into their legal reasoning (Cepeda 2005). Colombian judges see themselves as not

As stated by Foreign Affairs, that placed Colombia at the 14th position of its 'Failed States Index' in 2005.

Defined by Bayart, Ellis and Hibou, from the study of African situations, as 'the routinization, at the very heart of political and governmental institutions and circuits, of practices whose criminal nature is patent, whether as defined by the law of the country in question, or as defined by the norms of international law' $(1999,16)$ 
only recipients, but also creators of an international doctrine on human rights (Lecombe 2009). In short, even if the Colombian legal jurisdictions have been unable to prosecute a considerable number of human rights violations, they have succeeded in remaining the central political arena for addressing these issues.

Land grabbing has not been an exception to this rule. The issue of violent land grabbing has been initially problematized through the specific rights or internally displaced persons (IDPs). Furthermore, the intervention of international legal actors (the Interamerican Human Rights Commission and Court), but also domestic actors provoked the Colombian Constitutional Court's intervention in the case of the Lower Atrato. The special attention paid to this case is also a result of the mobilisation of a legal repertoire by local organisations and national NGOs. Yet interventions were not limited to this single case. The interest of the Constitutional Court on land grabbing also lead this institution to intervene on the broader subject of 'rural development'. The following pages will subsequently deal with the introduction of the human rights framework in the Colombian politics, the definition of internal displacement as a political issue and the establishment of a link between armed violence and land grabbing.

\section{Human rights: subversive or conservative?}

This section will tackle an apparent paradox, the fact that the judicialization of politics has been parallel with the aggravation of the armed conflict. The mobilisation of the human rights framework in order to problematize and politicise violence in Colombia has been a political strategy used both by social movements and the State. While the latter saw human rights as a source of legitimacy, the implementation of reforms, even if they were initially instrumentalized, led to the opening of new contentious arenas. In order to understand this interaction it is necessary to address the complex entanglement of contentious politics, diplomacy and public policies.

Since the early 1980s, the government, as well as the social movements, have asked for judicial responses to violence (Daviaud 2006). The emergence of human rights as a conflict arena has not been the automatic consequence of international pressure, but the result of a joint construction, involving international actors as well as domestic movements (Gallon 1997). The language of human rights was adopted by social organizations from the 1980s. It seemed particularly attractive, as it was a gate to international arenas, such as the United Nations Committee for Human Rights or the Interamerican Commission of Human Rights (Tate 2007). 
In Colombia, human rights organizations are heir to the 1960s' cause lawyers, who represented the presumed members of guerrilla organizations prosecuted by military justice. At the time, even if the country was governed by civilians, the military had a monopoly on security issues. Prosecuted individuals charged with 'terrorism' or 'subversion' where under the scope of martial law.

These legal networks constituted the basis of the first human rights organizations. They stayed focused on the defence of 'political prisoners', as well as on the denunciation of police and military brutality, and forced disappearance. The strategy of these pioneer organizations was initially focused on domestic courts (Daviaud 2006, Tate 2007). At the time, Colombia was seen by foreign countries as a stable democracy on a continent governed by military dictators (Gallon 1997; Pardo, Tokatlian 1989; Garibay, Guerrero 2007). Consequently, it was difficult to obtain the attention of international advocacy organizations.

Yet, from the end of the 1980s, the development of links between Colombian activists and foreign NGOs became one of the main vectors of professionalization in the human rights arena. For instance, contacts between Colombian lawyers and members of the Geneva-based International Commission of Jurists led to the creation of a Colombian branch of this organization (Tate 2007, 119). Such links were the necessary condition for the success of international advocacy campaigns. From the beginning of the 1990's, representatives of the Colombian NGOs lobbied at international forums, such as the UN Committee, and met American Congress members. They also took cases to the Interamerican Human Rights Courts, seeking to provoke a 'boomerang effect' (Sikkink, Keck 1998), so that international pressure materializes into domestic decisions.

From the end of the 1980s, international NGOs and networks of lawyers, have pointed out the responsibility of the state in the exactions committed by the military and paramilitary groups. In 1988 a judicial observation commission was set up. That same year, four international NGOs Americas Watch, Amnesty International, International Commission on Jurists and Pax Christi reported on the human rights situation in Colombia. Amnesty International highlighted specific cases, mentioning the names of the military suspected of murder and torture, arguing that 'the Colombian military forces have adopted a terror policy in order to intimidate and eliminate opposition' (Amnesty 1989 ).

Under this pressure, the government changed its discourse. The new strategy was aimed at recognizing the gravity of the situation and the commitment of the state in favour of peace and the rule of law (Daviaud 2006). From then on, the human rights frame was progressively incorporated by the establishment, in spite of its contentious origins. 
Yet, the appropriation of the human rights narrative was not limited to discourse. In the middle of a democratization process, which led to the establishment of a new constitution in 1991, a new institutional arrangement was promoted. Human rights started to be considered as the axis of the new democracy and a basis for peace-building. In consequence, new institutions, such as the People's Ombudsman (Defensor del Pueblo), were charged with the implementation of an undefined human rights policy (Ungar 2004).

The appropriation of the human rights discourse by the government may be interpreted as a propaganda strategy, aimed at the re-legitimization of the ruling elites through an institutional disruption. Indeed, NGOs and activists denounced, from the beginning of the 1990s, the fact that most of the policies intended to guarantee the rights of vulnerable populations were no more than empty shells, without any power or budget, used to enhance the international image of the Colombian government.

However, these reforms have been extremely ambivalent; the works of David Recondo (2007), who has studied the implementation of multiculturalism in Mexico, are very useful to understand the complexity of institutional change. No actor - he argues - even those who implement reforms, has full control over the course of events. Reforms, even those which are instrumentalized by the government, cannot be confined to one single group of decision makers. They involve a variety of actors who will try to direct them for personal benefits. Reforms often result from the convergence of antagonistic interests; as such, their outcome is rather unclear. In a context of democratization, new institutions, initially created to moderate social mobilization, can become fuel for new conflicts, redistributing resources and refining demands.

The case of the first Ombudsman illustrates the ambivalence of human rights institutions. Jaime Córdoba Triviño, a criminal attorney, started his career as an Inspection General's Office assistant. He represented his office at the Supreme Court, and was in charge of the human rights division. After being nominated as the People's Ombudsman, Córdoba Triviño was extremely active. He organized a series of investigative commissions, charged with determining the responsibility of the military in several murder cases. The most important of these commissions, in charge of the 'Trujillo Massacre', resulted in the recognition by the president of the State's responsibility in the torture and murder of more than 300 civilians by members of the army and paramilitary groups. Yet, the Ombudsman suffered from the gap between his political visibility and legitimacy and the complete lack of coercive power. His mission was to investigate and report about the human rights situation. The Ombudsman had no judicial function, as denunciations were transmitted to the 
Attorney General's office, the only jurisdiction competent to press charges. Yet, Córdoba Triviño was generally recognized as a human rights advocate inside the state, and his legitimacy as a jurist was recognized by his election as a Constitutional Court justice.

\section{The Constitutional Court and the issue of internal displacement}

The current section will briefly trace the intervention of the Constitutional Court in matters of forced displacement. The importance of this description is linked to the fact that the definition of forced displacement as a human and constitutional rights violation paved the way to the judicialization of land grabbing. As the end of the section will show, legal mobilisation against land grabbing has not been entirely focused on the legal rights over land, but more broadly on the link between the individual, the community and the territory, in a context of massive forced displacement.

Among the institutional reforms introduced by the 1991 Chart, one of the most outstanding has been the creation of the Constitutional Court. This organization, placed at the very summit of the legal pyramid, is defined as the watchdog of the Chart's integrity. It has interpreted civil and human rights in an extensive manner, in order to influence public policies in an extremely progressive direction. According to Blanquer $(2002,56)$, the Constitutional Court has become a policy maker, compensating the legislator's unwillingness to assume the defence of the rule of law. One of the specific points where the Court's influence has been pivotal is internal displacement. Its decisions have led to the recognition of the specific rights of internally displaced people. One of those specific rights - doubtlessly the most conflictive one - has been the right to recover violently grabbed land.

According to the Geneva based Internal Displacement Monitoring Center (IDMC), the internal conflict in Colombia has led to the displacement of 4.9 to 5.5 million people, ${ }^{10}$ which makes it the country with the second largest IDP population after Sudan. Yet, partially as a consequence of the fragmentation of the political order, internal displacement was considered for years as a marginal phenomenon. It concerned the poor population from the countryside, generally peasants from segregated peripheries, who migrated to the large cities. According to Lucas Gómez (2012), until the early 1990s decision makers and journalists had not perceived the link between armed conflict

10 Since the late nineties there has been continuous debate over the figures of internal displacement in Colombia. IDMC's different figures correspond to the Colombian government (the lowest assessment) and to the Colombian NGO CODHES (the highest) : Comisión de Seguimiento a la Política Pública sobre el Desplazamiento Forzado, 10 December 2010, Tercer Informe de Verificación sobre el Cumplimiento de los Derechos de la Población en Situación de Desplazamiento ; Consultoría para los Derechos Humanos y el Desplazamiento (CODHES), 19 September 2011, De la seguridad a la prosperidad democrática en medio del conflicto. 
and internal displacement. It was generally thought that IDPs were just the most recent wave of rural migration, something natural in a country marked by an extremely quick urbanization process during the second half of the century.

At the beginning of the 1990s, the growth of internal displacement became undeniable. Peasant families in every corner of the cities' streets were the living proof of its magnitude. The political reaction to internal displacement was long and rather chaotic. Initially, the problem was perceived as the inevitable consequence of the armed conflict. IDPs had the same rights as the victims of natural catastrophes, and there was no specific definition of their situation. Internal displacement was defined as the product of an accidental cause, thus closing the door to the establishment of particular responsibilities and/or the procurement of specific rights (Gómez 2012; Rodríguez, Rodríguez, 2010).

As shown by the sociology of public problems, the definition of an issue determines responses and subsequent institutional arrangements, or as Gusfield puts it: 'To give a name to a problem is to recognize or suggest a structure developed to deal with it' $(1989,432)$. The constructionist view on social problems invites us to be attentive to the impact of the definitional activities of social actors. In that respect, the Constitutional Court's first intervention was to name the problem of internal displacement, to define it as a human rights' violation; in so doing, judges established the state's responsibility and the specific rights of IDPs (Rodríguez, Rodríguez 2010)

The definition of IDPs as human rights violation victims was, in the first place, a claim made by NGOs and social organizations. The qualification of IDPs as a special population, protected by international law, was introduced around 1994, when the UN's special rapporteur for IDPs visited the country. Such international visibility gave a window of opportunity to domestic NGOs to increase the public and policy makers' awareness of the IDPs' lot. Despite large mobilization and despite the number of organizations advocating for the rights of this population, public policies remained innocuous, and did not address the issue of specific IDPs' rights.

The breaking point was a decision of the Constitutional Court; responding to a writ for protection of fundamental rights (acción de tutela), the Court stated that internal displacement was a massive and permanent violation of human rights. The judges established that the state was failing in its fundamental duties towards a particularly vulnerable population. They considered that the State had the obligation of elaborating a public policy specifically aimed at the protection of IDPs.

In the aftermath of its decision, the Court established a monitoring process, in order to enforce the rights it intended to protect. Public audiences organized to monitor the situation of IDPs became an 
institutional arena leading to the mobilization of social organizations and other political actors. The Court defined internal displacement as intrinsically linked to constitutional rights and to the maintenance of the rule of law; from that point, more than a political controversy, it became a legal issue.

\section{Legal action}

The legal mobilisation in the case of the Lower Atrato aimed at establishing a clear-cut relation between forced displacement and land dispossession, in order to problematize land grabbing, not as a conflict over land property and control, but as an issue of human and constitutional rights. This idea was advanced by NGOs under the form of a 'correlation between forced displacement and land usurpation' and a 'debate on land grabbed in blood and fire to more than 3 million displaced persons' (Comision Colombiana de Juristas 2006, 7-10).

In compliance with some of the provisions of the new 1991 constitution, the Colombian congress passed Law 70 in 1993, establishing a new legal framework for the protection of collective property and ethnic identity of the black communities of the Pacific coast. The law defined 'black communities' as collective recipients of multicultural rights, thus contributing to create a specific 'black' identity (Cardenas, 2012). Among the possibilities opened by Law 70, was the recognition of property rights over land under the form of collective titles. This provision involved the organization of 'community councils', a local government form aimed at representing the interests of the community as a collective subject. Collective titles have a particularly solid legal protection; they are unalienable and indivisible. Following the mandate of the law, the Colombian Institute for Rural development granted collective title deeds over more than five million hectares of the Pacific lowlands.

Law 70, apparently securing community property rights over land, was expected to revert the landgrabs. Predictably, it provoked harsh opposition among the most conservative sectors of landholders, who even claimed that the law had a 'subversive origin', as stated by a businessman:

We are deeply concerned (...) for the more than 6 million hectares of the Colombian Pacific lowlands that had been conquered with dark purposes by Law 70 and its famous community councils, imposed by the law of the subversive rifle. ${ }^{11}$

11 Source: Comisión Intereclesial Justicia y Paz, Informe 64. Deforestación ilegal hacia el Jiguamiandó, 15 December 2007. 
Using the legal possibilities offered by Law 70, the inhabitants of the Lower Atrato created the Great Community Council of Jiguamiandó and Curvaradó, coordinating minor councils and paving the way for the procurement of collective rights over their land. A collective title deed was issued in December 2000, apparently securing these communities' rights to land. This achievement, intended to secure the population's rights over the land, was not the automatic result of the provisions of the law. It was also the consequence of a process of collective organization, specially forged in the aftermath of their experience of forced displacement. Moreover, their cause attracted NGOs interested in supporting collective action, and taking the case to legal jurisdictions. The shared trauma created solidarity links among the local inhabitants and led to their identification as a collective actor. According to Rolland (2007), collective action is intrinsically linked to territorial identity, as it is primarily aimed at the delimitation of a protected territory, under the form of 'humanitarian zones' or 'peace communities'. Social movements built a discourse based on legal national and international provisions that stresses the neutrality of the civil population and the specific rights of ethnic minorities. At the same time, they adopted an attitude of autonomy and opposition to the state, considering that its representatives are intimately linked to paramilitary groups. The ambiguity of this mobilisation follows the fact that it aims to transform individuals and communities into legal subjects, yet the State is still perceived as an illegitimate actor.

Indeed, the procurement of the collective title deeds did not mark the end of the mobilization, but only the beginning of a new contentious cycle. A few months after the signature of the agreements, a new paramilitary offensive caused waves of forced displacement, reducing the recently acquired property right to an abstract claim. Most of those who were already mobilized around the collective titles refused to seek refuge in the surrounding towns, and preferred to stay in the refugee camps, not far from their land. The same pattern was repeated several times between 2003 and 2007, while palm crops were profusely cultivated. Altogether, from 1996 to 2007, 13 cases of massive forced displacement were reported, and 115 civilians were murdered in this zone. ${ }^{12}$

The community councils and their legal advisor, the Colombian NGO Justicia y Paz, required the intervention of competent authorities. They initiated a criminal complaint against members of the 17th Brigade of the army, and most notably its commander at the time of the first bombings, General Rito Alejo del Rio. They also asked for the immediate protection of the lives and lands of the forcibly displaced communities. An action for protection was referred to the People's Ombudsman. Its response - issued in 2002 - was the first intervention of a public authority on behalf of the Lower Atrato communities. The Ombudsman recognized the violations presumably

Ibid. 
committed by members of the army and paramilitary militias against the local inhabitants. Most importantly, the Ombudsman recognized the link between the forced displacement and the development of palm crops. Its report stated that: 'palm crops have been illegally developed, by individuals and firms unconnected to the communities (...) thus violating the basic rights of the Black communities.' ${ }^{, 13}$

This link rapidly became one of the central issues of the controversy around forced displacement and land grabbing. The government was willing to acknowledge its duties concerning the protection of the displaced families - although without taking concrete measures - but was fiercely opposed to establishing any link between armed violence and land grabbing.

Despite the recognition by the Ombudsman of the egregious violence the Lower Atrato people had suffered, its report did not trigger off any official intervention. Moreover, the criminal case against the military was at a dead end. In 2001, the chief of the human rights unit at the Attorney General's office obtained the indictment of General Del Rio. Following the demand of the victims' representative - Justicia y Paz, the already mentioned NGO - the act of indictment mentioned the crime of 'paramilitary conspiracy' as well as the forced disappearance of more than 150 people. Yet, the recently nominated Attorney General, Luis Camilo Osorio, withdrew the indictment, took the case and started a disciplinary investigation against the former prosecutor. Osorio, a jurist known for his conservative positions, had already declared to the press that he considered that the Attorney General's Office had a pro-guerrilla bias and expected to 'redress the balance'. The Del Rio case remained at a dead point for three years, and Osorio finally dismissed it in $2004 .^{14}$

The lack of protective measures covering the Lower Atrato people, as well as the manipulation of the criminal inquiries, led the representatives of the communities to bring a complaint before the Interamerican Commission for Human Rights. Following the complaints, the Commission organized an official visit in December 2001, a few months after a violent campaign of harassment against the Lower Atrato communities, perpetrated by paramilitary militias and the military. For two years, the Commission accumulated an important amount of data about human rights violations, and especially about the link between violence and land-grabbing. The Commission documented the existence of palm crops illegally planted by the firm Urapalma. The firm, connected to the paramilitary militias, occupied the land that had already been allocated to the

\footnotetext{
13 Resolución defensorial $\mathrm{N}^{\circ} 25$, October 2002. Violaciones masivas de derechos humanos y desplazamiento forzado en la región del Bajo Atrato chocoano.

14 Author interview with the attorney in charge of the first indictment against Del Rio. Bogota, February 2011.
} 
communities; its facilities were protected - according to the Commission - both by paramilitary militias and men of the 17th Brigade of the army.

In March 2003, after two years of inquiry and monitoring by the Commission, the Interamerican Court issued provisional protection measures, covering the communities of the Lower Atrato. This legal act engaged the Colombian state to protect the beneficiaries, under the terms of the American Convention on Human Rights. Considering the fact that the prevention measures adopted by the Commission had not produced any effect, the Court summoned the Colombian state to provide effective protection to the Lower Atrato People, and to investigate the criminal facts that had been denounced by the Commission. ${ }^{15}$

The Commission required the recognition of the link between armed violence and land grabbing, and declared that the paramilitary violence and the army operations, were both aimed at facilitating the occupation of the land for purposes of oil palm production:

\begin{abstract}
Since the year 2001, Urapalma corporation has promoted oil palm crops in approximately 1500 hectares of land belonging to the collective territory of the communities (...) The operations and armed incursions into this territory have pursued the objective of intimidating the members of the communities, in order to force them to associate to palm production or to leave the region. ${ }^{16}$
\end{abstract}

The most controversial issue raised by the Interamerican Court's intervention was the link between forced displacement and land grabbing. The Commission's memorandum specifically pointed to land exploitation as the underlying motivation behind the armed operations. Yet, the Court did not mention this issue in its 2003 conclusions. In the aftermath of the first resolution, the Court received diverse monitoring reports from the Commission, as well as the communities' representatives. These reports stressed the fact that land grabbing had continued, and was part-and-parcel of the multiple human rights violations endured by the Lower Atrato people. In the meantime, the Colombian government had the obligation of reporting to the Court on the measures taken to protect the communities. The documents produced by the government representatives stated that the monitoring of palm crops was not required by the Court's decision. In addition, these reports affirmed that palm entrepreneurs had respected the limits of the collective lands, and denied any link between palm business and armed violence.

\footnotetext{
15 Corte Interamericana de Derechos Humanos. Resolución. Asunto comunidades del Jiguamiandó y del Curbaradó. March 6, 2003

16 Ibid.
} 
Yet, the Interamerican Court and Commission's intervention progressively led to a series of public inquiries, which shed light onto the mechanisms of violent land grabbing. This intervention created a new advocacy and bureaucratic field, and enhanced the legitimacy of the issue as a public policy problem. In 2005 the General Inspector's Office ${ }^{17}$ issued an official report recognizing the responsibility of the state as it failed to protect the Lower Atrato communities from paramilitary and military violence. It was the first official conclusions that gave credit to the community representatives' claims. Yet, the link between violence and land grabbing was only marginally addressed, and did not lead to specific conclusions or procedures.

This recognition came from a different public agency. In 2005, the Colombian Institute for Agricultural Development (INCODER) reported the land grab of almost four thousand hectares in the Lower Atrato. The agribusiness investors were depicted as opportunistic actors, who profited from forced displacement to develop palm crops in the collective land. ${ }^{18}$ By this, no reliable information was available on the collusive links between business actors and paramilitary militias, even if the hypothesis was already evoked.

Yet, the immediate impact of this action was reduced; a few months after the publication of the report, a second INCODER document stated that most of the investors' title deeds were legal, and had been legitimately purchased. A subsequent Ombudsman report severely criticized this revocation and confirmed the initial information. ${ }^{19}$

The turning point of the land grabbing controversy was the recognition by the Interamerican Court of the link between land grabbing and forced displacement. In its March 2005 resolution, the tribunal established that palm crops were the main cause of forced displacement, and a severe obstacle to the local families' return. The Court's intervention accorded a high level of recognition to the NGOs' claims, and denounced the government's official discourse that had refused to link land grabbing and forced displacement.

The Interamerican Court's provisions were assumed by several domestic institutions. In 2006, the General Inspector's Office issued a report recognizing land grabbing as one of the main causes of forced displacement. According to this data, 76 percent of IDPs in Colombia were peasants at the moment of their forced displacement. 'Land grabbing, dispossession and plundering' are considered to be a part of a 'counter agrarian reform' mostly perpetrated by paramilitary groups in alliance with

17 The General Inspector's Office is in charge of controlling the public servants' compliance to the law

18 Source: Incoder Los cultivos de palma de aceite en los territorios colectivos de las comunidades negras de los ríos Curvaradó y Jiguamiandó, en el departamento del Chocó. 2005.

19 Source: Defensoría del Pueblo (2006) Informe de seguimiento de la Resolución Defensorial No. 39 del 2 de junio de 2005 
corporate actors. ${ }^{20}$ Moreover, 'indigenous peoples' and 'Afro-Colombian communities' are considered to be particularly vulnerable to violent land grabbing. The General Inspector's Office then analyses what is called a 'political ecology of war' and considers the cases of the Lower Atrato, where, 'those who came back to their lands, in the aftermath of forced displacement, found them covered with oil palm crops'. ${ }^{21}$ Based on those observations, the report pleads for an integration of issues of land control and land grabbing into the public policy of IDP's assistance.

The interaction between national and international institutions contributed to create a contentious arena for NGOs as well as domestic jurisdictions. In 2009, the Constitutional Court pointed to the noncompliance of the Interamerican Court's provisions by the Colombian government. In one of the internal displacement monitoring acts, the Court stated that the government had failed to protect the rights of the Lower Atrato people. Based on data provided by the Ombudsman and the General Inspector's offices, the Court dictated the parameters of a specific plan that would address the necessities of the Lower Atrato people. It ordered the relevant ministries and agencies to determine the threats to the collective title deeds. ${ }^{22}$

The judicialization of land grabbing was not limited to the case of the Lower Atrato, which I have used here to illustrate the interaction between national and international legal arenas, as well as the link between land control issues and internal displacement. The intervention of the Constitutional Court in the case of the 'rural development statute' (Law 1152 of 2007) is also a relevant case of judicialization of land grabbing. The law had a clear-cut business approach of land, considering that rural development in a context of globalisation 'requires a new impetus to business development and a key role reserved to the private sector'. The stress was put on 'improvements in the profitability and competitiveness of (agricultural) products'. ${ }^{23}$ The law was harshly criticized by NGOs and representatives of peasant organisations and IDPs. The provisions aiming to 'rationalize' and 'clarify' land property were interpreted by these organisations as a threat to small peasants and ethnic communities. Moreover, several mechanisms that were intended to facilitate the issuing of title deeds were also seen as a legalisation of violent land grab. The law intended to redistribute land that was considered to be abandoned or unexploited. However, the causes of abandonment were not

$20 \quad$ Procuraduría General de la Nación, Proyecto Control Preventivo y Seguimiento a las Políticas Públicas en Materia de Reinserción y Desmovilización, Capítulo 2, Seguimiento a la protección de las víctimas del conflicto en materia de bienes patrimoniales. Descripción, Análisis y Seguimiento, Bogotá, Procuraduría General de la Nación, 2006. P. 156

21 Ibid. p. 157.

22 Source : Corte Constitucional. Auto 005/09. M.P. José Manuel Cepeda Espinosa. 26 January 2009.

23 Source : Ley 030 de 2006-Senado, por la cual se dicta el estatuto de desarrollo rural, se reforma el Instituto Colombiano de Desarrollo Rural (INCODER), y se dictan otras disposiciones. 
addressed; in consequence, the law might lead to massive land-grabs in the zones affected by internal displacement.

In 2009, the Constitutional Court ruled that the 'rural development statute' was unconstitutional. The case against the law had been brought by the Colombian commission of jurists, an NGO associated with the ICJ (International Commission of Jurists). The NGO's arguments concerned the violation by the Colombian government of the Indigenous and Tribal Peoples Convention, an International Labour Organisation Convention that was ratified by the Colombian parliament in 1991. According to the Colombian Constitution and to the Court's jurisprudence, the text is a part of the 'constitutional block'. Yet, one of its key provisions (article 6) concerns the necessity to 'consult the peoples concerned, through appropriate procedures and in particular through their representative institutions, whenever consideration is being given to legislative or administrative measures which may affect them directly'. According to the Court 'the rural development statute constitutes a comprehensive regulation on use, distribution, and use of agricultural property'. Therefore, it affects directly the indigenous and Afro-Colombian communities, as 'the vast majority of them live in rural areas' and they 'have a special bond with the land, derived from their traditions and customs that are constitutive of their identity'. ${ }^{24}$

\section{Conclusion}

This contribution has argued that the Colombian case can be heuristic for the study of the coconstruction of legal institution in charge of the enforcement of the rule of law and the protection of property rights. As shown by the Lower Atrato case, these institutions are the product of the interaction between international law, institutional changes affecting the centre and grassroot mobilization. Moreover, the response of the Colombian State to land grabbing, and more broadly to forced displacement cannot be interpreted as merely a result of international pressure. Power balances inside the state apparatus but also mobilization from below are necessary factors to institutional change.

While this contribution has been mainly focused on the process of judicialization of land grabbing, two other issues can affect, in the following years, both the situation of Colombian peasants and the implementation of public policies: the impact of legal struggles on collective action and the integration of land grabbing in a broader field of 'peace policies'. We will conclude by briefly examining these two issues.

$\overline{24}$ Colombian Constitutional Court. Decision C-175/09. 18 March 2009 
Firstly, the emergence of 'patterns of contention' (Boudreau 2004), namely the result of the interaction between land grabbing and social mobilisations, is intimately linked to legal arenas. According to Sandoval (2013), the direct impact of judicial decisions on social change in Colombia is reduced. Legal provisions only concern specific cases of individuals (as in the Lower Atrato communities) or are focused on judicial review (as in the 'rural development statute'). The Constitutional Court's decisions do not challenge the economic model and the political ecology of agribusiness. However, this same author argues (Sandoval 2013, 212), legal decisions constitute a basis for further mobilisations; they impulse the emergence of public problems (as in the case of internal displacements analysed by Gomez 2012) and enrich the movements' repertoire with new legal and political skills. Other scholars, such as Lemaitre (2009), stress the fact that legal struggles are key moments for the formation of collective identities and the constitution of individuals and groups as legal subjects.

Secondly, we have argued that legal struggles maintain a close link with institutional change. By the 2010 presidential election, the issue of land grabbing and land-related violence had become a legitimate public problem. Following his election, the new president Juan Manuel Santos announced his commitment to the enactment of an ambitious 'Land and Victims Law'. The bill would benefit the several million people who suffered personal or material damage from the action of organized armed actors, including those whose land was extorted by violent entrepreneurs.

The enactment of the Land and Victims Law opened a window of opportunity for peasant and IDPs' organisations. It gave visibility to their cause and it permitted them to point to specific cases of violent dispossession and to obtain media attention. Yet, this visibility also exposed collective and individual actors to violence; according to the Ombudsman bureau, at least 71 leaders of peasant organizations were murdered between 2006 and $2011 .^{25}$ In June 2012, more than 15000 people had addressed formal complaints for land restitution. Several hundreds have asked for special police protection, following murder threats linked to their demands.

Land grabbing and land reform have been integrated into the agenda of the peace process currently held between the Colombian government and the FARC guerrilla. ${ }^{26}$ While the issue of the peace negotiations is still unknown, the implementation of new policies of rural development that will take into account the necessities of peasants, indigenous and afro-descendants has been defined by the government as a necessary step in the process of peace building. As such, our retrospective analysis has shown that the judicialization of land grabbing in Colombia has been a key step in the

25 Defensoría del Pueblo, comunicado de prensa, 28 de marzo de 2012.

26 Fuerzas Armadas Revolucionarias de Colombia - Revolutionary armed forces of Colombia. 
process of defining land not only as an object of business transactions but also as an issue of human rights and collective identities.

\section{References}

Angell A., Schjolden L. \& Sieder R. eds. 2005. The Judiciarization of Politics in Latin America, New York: Palgrave Macmillan.

Amnesty International, 1989. Colombia: El panorama de los derechos humanos, Londres.

Avilés W., 2007. Global Capitalism, Democracy, and Civil-Military Relations in Colombia, SUNY Press.

Ballvé T., 2013. Grassroots masquerades: Development, paramilitaries, and land laundering in Colombia. Geoforum, 50, p.62-75.

Barbosa J., Renán W., Suárez W. 2007. La propiedad rural en el Magdalena 1970-2004 y algunas relaciones con el desplazamiento forzado. Santa Marta, DTCH: Universidad del Magdalena, Vicerrectoría de Investigación, Fonciencias, Sección II, informe final convocatoria 2004.

Bayart J.-F. \& Hibou B., 1999. The Criminalization of the State in Africa, International African Institute.

Blanquer J-M. 2002. Colombie: les droits sans Etat. Problèmes d'Amérique Latine. 44, 49-62.

Borras S., Franco J. 2013. Global Land Grabbing and Political Reactions 'From Below'. Third World Quarterly. 34 (9), 1723-1747.

Boudreau V. 2004. Resisting Dictatorship, Repression and Protest in Southern Asia. Cambridge: Cambridge University Press.

Bushnell D., 1993. The making of the modern Colombia: a nation in spite of itself, Berkeley: University of California Press.

Cárdenas R., 2012. Green multiculturalism: articulations of ethnic and environmental politics in a Colombian ‘black community’. Journal of Peasant Studies, 39(2), p.309-333.

Cepeda M.J. 2005. Judicialization of Politics in Colombia: the old and the new. In A. Angell L. Schjolden, \& R. Sieder, eds. The Judiciarization of Politics in Latin America. New York: Palgrave Macmillan, p. 67-104. 
Comaroff J. \& Comaroff J.L., 2008. Law and Disorder in the Postcolony: an introduction. In Law and Disorder in the Postcolony. Chicago: University of Chicago Press.

Comisión Colombiana de Juristas, 2006. Revertir el destierro forzado: protección y restitución de los territorios usurpados. Obstáculos y desafíos para garantizar el derecho al patrimonio de la población desplazada en Colombia, Bogotá.

Cousins B. 2009. Capitalism obscured: the limits of law and rights-based approaches to poverty reduction and development. Journal of Peasant Studies. vol. 36, no 4, p. 893-908.

Daviaud S. 2006. Droits de l'homme et politique. L'enjeu des droits fondamentaux dans le conflit colombien. Paris : EHESS.

Duffy R., 2008. «Shadow state»: mondialisation, criminalisation et changements environnementaux au Belize. In J.-L. Briquet \& G. Favarel-Garrigues, eds. Milieux criminels et pouvoir politique. Les ressorts illicites de l'Etat. Paris: Karthala.

Duncan G., 2005. Los señores de la guerra, Bogota: Planeta.

Escobar A., 2008. Territories of Difference: Place, Movements, Life, Redes, Duke University Press.

Fox J. 1994. The Difficult Transition from Clientelism to Citizenship: Lessons from Mexico. World Politics. Vol 46, no. 2, p. 151-184.

Gallón G. 1997. Diplomacia y derechos humanos: Entre la inserción y el aislamiento. In Ramírez $\mathrm{S}$, Restrepo L eds. Colombia entre la inserción y el aislamiento. La política exterior colombiana en los años noventa. Bogotá : IEPRI-Siglo del Hombre.

Garibay D., Guerrero J.-C., 2007. Identifier et interpréter une «crise extrême». La «communauté internationale» face au conflit armé en Colombie. In Le Pape, Siméant, Vidal (eds) Crises extrêmes. Paris: La Découverte.

Gayer L., 2014. Karachi: ordered disorder and the struggle for the city, Oxford University Press.

Gibson E. 2005. Boundary Control Subnational Authoritarianism in Democratic Countries. World Politics. vol. 58, p. 101-32.

Goebertus Estrada J., 2008. Palma de aceite y desplazamiento forzado en Zona Bananera:« trayectorias » entre recursos naturales y conflicto. Colombia internacional, $\mathrm{n}^{\circ} 67$, p.152-175. 
Goldfarb L., 2012. The frontiers of genetically modified soya in Argentina. Possession Rights and New Forms of Land Control and Governance. In International conference on global land grabbing. Ithaca, Cornell University.

Gómez L. 2012. Le déplacement forcé par la violence en Colombie: émergence, réinscription et transformations d'une nouvelle catégorie de l'action publique. Paris : Sciences Po.

Grajales J., 2011. The rifle and the title: paramilitary violence, land grab and land control in Colombia. Journal of Peasant Studies, 38(4), p.771-792.

Grajales J., 2013. State Involvement, Land Grabbing and Counter-Insurgency in Colombia. Development and Change, 44(2), p.211-232.

Gusfield J. 1989. Constructing the Ownership of Social Problems: Fun and Profit in the Welfare State. Social Problems. vol. 36, no 5, p. 431-441.

Gutierrez Sanín F. 2007. Lo Que El Viento Se Llevo?: Los Partidos Politicos y La Democracia En Colombia, 1958-2002. Bogotá : Norma.

Leal Buitrago F, Dávila A. 1990. Clientelismo. El sistema político y su expresión regional. Bogotá : Tercer Mundo - IEPRI.

Lecombe D. 2009. Trust and distrust about the diffusion of transitional justice in Colombia. International Political Science Association Congress, Santiago de Chile.

Lemaitre Ripoll J. 2009. El derecho como conjuro. Fetichismo legal, violencia y movimientos sociales. Bogotá : Siglo del Hombre (Derecho y Sociedad).

Li T.M. 2011. Centering labor in the land grab debate. Journal of Peasant Studies. vol. 38, no 2, p. 281-298.

López-Alves F. 2003. La Formación del Estado y la Democracia en América Latina: 1810-1900. Bogotá : Norma.

Lund C. 2011. Fragmented sovereignty: land reform and dispossession in Laos. Journal of Peasant Studies. vol. 38, no 4, p. 885-905.

Lund C, Peluso N. 2011. New frontiers of land control: Introduction. Journal of Peasant Studies. vol. 38, no 4, p. 667-681. 
Monsalve S. 2012. The Human Rights Framework in Contemporary Agrarian Struggles. Journal of Peasant Studies. Ifirst article.

Oslender U. 2007. Violence in development: the logic of forced displacement on Colombia's Pacific coast. Development in Practice. vol. 17, no 6, p. 752-764.

Pardo R, Tokatlian J.G. 1989. Política exterior colombiana: de la subordinación a la autonomía? (Colección Uniandes 40 años).

Pécaut D. 2006. Crónica de cuatro décadas de política colombiana. Bogota: Norma.

Romero M. ed., 2007. Parapolítica. La ruta de la expansión paramilitar y los acuerdos políticos, Bogotá: Corporacion Nuevo Arco Iris.

Romero M. ed., 2011. La economía de los paramilitares, Bogotá: Random House Mondatori.

Recondo D. 2007. La Política Del Gatopardo: Multiculturalismo y Democracia en Oaxaca. CIESAS.

Reno W., 2008. Corruption and State Politics in Sierra Leone, Cambridge University Press.

Restrepo Echeverri J., Franco Restrepo V. 2011. La toma de la tierra: lógicas de guerra y acumulación en el Bajo Atrato. In Romero M ed. La economía de los paramilitares. Bogotá : Random House Mondatori.

Rodriguez Garavito C., Rodriguez Franco D. 2010. Cortes y cambio social. Como la Corte Constitucional transformó el desplazamiento forzado en Colombia. Bogotá : Dejusticia-Antropos.

Roldan M. 2002. Blood and fire: la Violencia in Antioquia, Colombia, 1946-1953. Duke University Press.

Rolland S., 2007. De l'individuel au collectif: Des stratégies de survie des déplacés colombiens aux regroupements communautaires. Asylon(s), (2).

Sandoval Rojas N., 2013. La movilización social en tiempos de la Constitución: feministas, indígenas y víctimas de crímenes de Estado ante la Corte Constitucional colombiana. Colombia Internacional, (79), p.191-217.

Sikkink K, Keck M. 1998. Activists beyond borders. Cornell University Press.

Tate W. 2007. Counting the Dead: The Culture and Politics of Human Rights Activism in Colombia. Berkeley : University of California Press. 
Taussig M., 2003. Law in a lawless land, diary of a limpieza in Colombia, New York: The New York Press.

Ungar M., 2004. Human rights in the Andes. The Defensoría del Pueblo. In J.-M. Burt \& P. Mauceri, eds. Politics in the Andes. Pittsburgh: University of Pittsburgh Press.

Uprimny R. 2007. La justice au cœur du politique: potentialités et risques d'une judiciarisation en Colombie. In Commaille J, Kaluszynski M eds. La fonction politique de la justice. Paris : La Découverte.

Vermeulen S., Cotula L. 2010. Over the heads of local people: consultation, consent, and recompense in large-scale land deals for biofuels projects in Africa. Journal of Peasant Studies. vol. 37, no 4, p. 899. 